Winter 2012

\title{
Organization Change and Social Organizing Strategies: Employee-Initiated Organization Development.
}

Rod P. Githens

University of Louisville, rgithens@pacific.edu

Follow this and additional works at: https://scholarlycommons.pacific.edu/ed-facarticles

Part of the Business Administration, Management, and Operations Commons, Education Commons, and the Organization Development Commons

\section{Recommended Citation}

Githens, R. P. (2012). Organization Change and Social Organizing Strategies: Employee-Initiated Organization Development.. Human Resource Development Quarterly, 23(4), 487-518. DOI: 10.1002/hrdq.21148

https://scholarlycommons.pacific.edu/ed-facarticles/118 


\title{
Organization Change and Social Organizing Strategies: Employee-Initiated Organization Development
}

\author{
Rod Patrick Githens \\ University of Louisville
}

An edited version of this paper was published as:

Githens, R. P. (2012). Organization change and social organizing strategies: Employee-initiated organization development. Human Resource Development Quarterly, 23(4), 487-518.

\begin{abstract}
Lesbian, gay, bisexual, transgender, and queer (LGBTQ) employees create formal and informal groups within workplaces to provide social support and to seek organizational change at their places of employment. I present a case study of a coalition of these groups working together to attain domestic partner benefits within a large three-campus university system. These groups worked together to conduct employee-initiated organization development (OD). This development occurred through various approaches to organizational change and social organizing strategies. The study illustrates the distinct differences between employee-initiated OD in the corporate sector and in universities. The study demonstrates differences in organizing through a structured activist group and a looser grassroots coalition at various stages of the effort. Successes were attained at various stages through both the more highly structured groups and through loose-knit coalitions. Additionally, this study illustrates successes in social organizing around both fixed, ethnic-type identities and through more fluid queer approaches. Both approaches were utilized to varying degrees as the activists worked toward goals of concern to (a) diverse groups (not just LGBTQ individuals) and (b) LGBTQ-specific constituents.
\end{abstract}

Keywords: Workplace Diversity, Sexual Orientation, HR Benefits Policy

Over the last 25 years LGBTQ employees have made strides in becoming accepted in their workplaces due to individual attitude shifts, progressive societal changes, and organizational policies that promote diversity. Individual LGBTQ employees come together in a variety of ways to seek change and provide social support to each other. These formal and informal groups of employees exist in a variety of organizational sectors, differ in how they are organized, and serve a variety of purposes (Raeburn, 2004). The number of formal, organized networks in Fortune 1000 companies (i.e., the top 1000 publicly-traded U.S. companies, based on revenue) grew from two in 1980 to 69 in 1998 to 220 in 2012 (Human Rights Campaign Foundation, 2012; Raeburn, 2004)

As employee groups are formed, many need to justify their existence if they seek official organizational recognition. Employer-recognized groups are usually expected to help create competitive advantage or improve organizational effectiveness. Therefore, these groups must balance their activist agendas with the need to contribute to the organization. This balancing act can be understood through Fenwick's (2004) call for seeking "small wins" within organizations and through Meyerson and Scully's (1995) idea of "tempered radicalism." These ideas help us to understand how activists sustain their motivation when making slow progress and how these individuals serve both the needs of their employers and fulfill their drive for social justice. However, other groups exist without formal employer recognition, either because they are 
informal and unstructured or because their goals are incompatible with the goals of their employer.

In addition to working explicitly for changes within the organizations, employee groups serve less activist-oriented goals by providing social support and networking opportunities for LGBTQ employees and allies. These less political needs are a key factor in why employees become involved in the groups. The groups provide a place for activists and non-activists to meet others with similar identities, which help them both in persisting in working for LGBTQ-friendly changes and in helping them in their quest to openly exist as LGBTQ people. In that sense, these groups can bring about organization change less explicitly by providing visibility for an oftentimes-invisible segment of the workforce.

\section{Unexplored Questions}

Both the activist-oriented aims and social support roles of LGBTQ employee groups overlap in several regards. Even LGBTQ groups that shun politics and change still bring about organizational change since their very existence creates LGBTQ spaces within workplaces. These groups come in many different forms and make changes in different ways. HR professionals, leaders of LGBTQ groups, and scholars can learn from examinations of such changes within other organizations. From an employer perspective, understanding how these groups succeed helps in efforts to maintain positive employee-employer relations. When employee groups have failed due to the perceived lack of genuine organizational support or due to a hostile organizational climate, workers have become frustrated or angry (Bierema, 2005). When they succeed, these groups have the potential of fostering a friendly workplace culture, which can ultimately serve the employers' interests through increasing productivity and organizational effectiveness. From a social justice perspective, studying these groups helps others to understand how to bring about positive social change within a workplace context.

In order to serve these purposes, past studies have examined the process of change efforts undertaken by LGBTQ employee groups (e.g., Colgan, Creegan, McKearney, \& Wright, 2006; Colgan \& Ledwith, 2000; Raeburn, 2004; Scully \& Segal, 2002; Taylor \& Raeburn, 1995). However, questions remain unexplored. For example, is it more productive to work on these lobbying and education efforts using identity politics approaches in which LGBTQ people present themselves as an interest group and persuade others of their plight? Or, is it preferable to eschew notions of fixed LGBT ${ }^{1}$ identity and work with broader coalitions on issues of interest to both LGBTQ employees and others? Other studies have explored organization development and change efforts within universities, but have neglected consideration of grassroots and employeeinitiated social changes within university environments (e.g., Torraco, 2005). Considering the complexities and multiple stakeholders in a public university environment, what is the process for bringing LGBTQ-friendly organizational change in that setting? Bierema's (2010) model of critical OD advocates (a) understanding the context, (b) critiquing the influences on the issue, and (c) learning through action and reflection in order to improve the overall well-being of an organization. When considering approaches to OD like Bierema's, which integrate social and cultural critique, what is the interplay between workplace change, critique of the setting, and LGBTQ issues? The examination of such issues resulted in insights that can contribute to our knowledge of these groups, in addition to raising other questions and issues for further research.

\footnotetext{
${ }^{1}$ I have used "LGBTQ" and "LGBT" purposely throughout this study. In cases where LGBT or LGB are used, there is a specific focus on those categories and/or a distinct separation from queerness, which is explained later.
} 


\section{Purpose of the Study}

Workplace activists have made significant gains in attaining benefits, changing policies, and improving the work climate for LGBTQ workers. This study focused on understanding the process through which these changes had been sought in one workplace, as employees had come together to work for changes. Specifically, this study focused on the system-wide process of attaining domestic partner benefits (DPBs), equitable employee benefits for both unmarried partners of employees and spouses of employees in heterosexual marriages. The main question was "What is the process for employee groups to bring about LGBTQ-friendly changes in a university setting?" The investigation focused on two areas, which included:

1. LGBTQ activists' orientations toward organizational development and change in attempting to attain DPBs.

2. Activists' management of the sometimes-contradictory use of identity politics and queer approaches to organizing.

\section{LGBTQ Employee Groups and HRD}

In a broadly conceptualized field of human resource development (HRD), in which issues of social justice, power, and politics are openly discussed, LGBTQ issues are readily accepted as legitimate topics for HRD discourse (Bierema \& Cseh, 2003). These issues have real implications for the continuing development of people and organizations. LGBTQ employee groups relate to HR practice because many of them are associated with HR departments or are considered under the broad realm of employee relations. These groups are also related to $H R D$ because of the development and learning that takes place as a result of these groups: for individuals within the groups, by individuals outside the groups, and by organizations and societies in general that are affected by the formal and informal education, awareness, and change efforts that result from the employee groups. Workers often join these groups for reasons related to personal growth and development (e.g., to live more integrated lives), which can be a significant problem for LGBTQ employees (Creed \& Scully, 2000; Risdon, Cook, \& Willms, 2000). These groups often help to increase managers' and workers' awareness of LGBTQ issues. Additionally, the groups help to develop organizations and societies by expanding the accepted notions of sexuality in workplaces.

\section{Theories of Organizational Change and Approaches to Employee Groups}

LGBTQ employee groups, like most organizations or small groups, differ in their ultimate goals for existence. Organizational change can be aimed toward improving organizational effectiveness or toward broader social goals, which can include the betterment of society (Whittington, 2001). Organizational change can also be aimed at some combination of those two extremes.

Like other groups, LGBTQ employee groups also vary in their orientation toward the nature of organizations and the structure (or lack of structure) required to successfully meet their goals, regardless of their reasons for seeking those goals. When considering the nature of organizational change, individuals and organizations differ on the degree to which they are influenced by the view that organizations tend toward order or toward chaos (Burrell \& Morgan, 1979). If organizations tend toward order, systematization is sought. If they tend toward chaos, emergent thinking is embraced. In other words, leaders' and workers' attitudes toward organizational change vary depending on their perspectives regarding the "holistic or fragmentary nature" (Fisher, 2005, p. 240) of organizations and whether organizational change 
occurs through methodical action or emerges through the informal or bottom-up efforts by individuals (Whittington, 2001).

In order to understand the organizational diversity among LGBTQ employee groups, I used a framework for viewing these groups (Githens \& Aragon, 2009; depicted in Figure 1), using the concepts outlined above from the organization theory literature. This figure shows two continuums that help to add perspective to the varying orientations under which the groups operate. The left and right sectors depict the level of focus on (a) an orientation toward social change or (b) a focus on improving organizational effectiveness. LGBTQ employee groups exist on multiple locations on the continuum, rather than being solely in one camp or the other. Regarding their organizational structure, the top and bottom sectors depict the degree to which there is (a) an embrace of chaos and emergent thinking or (b) a striving toward order.

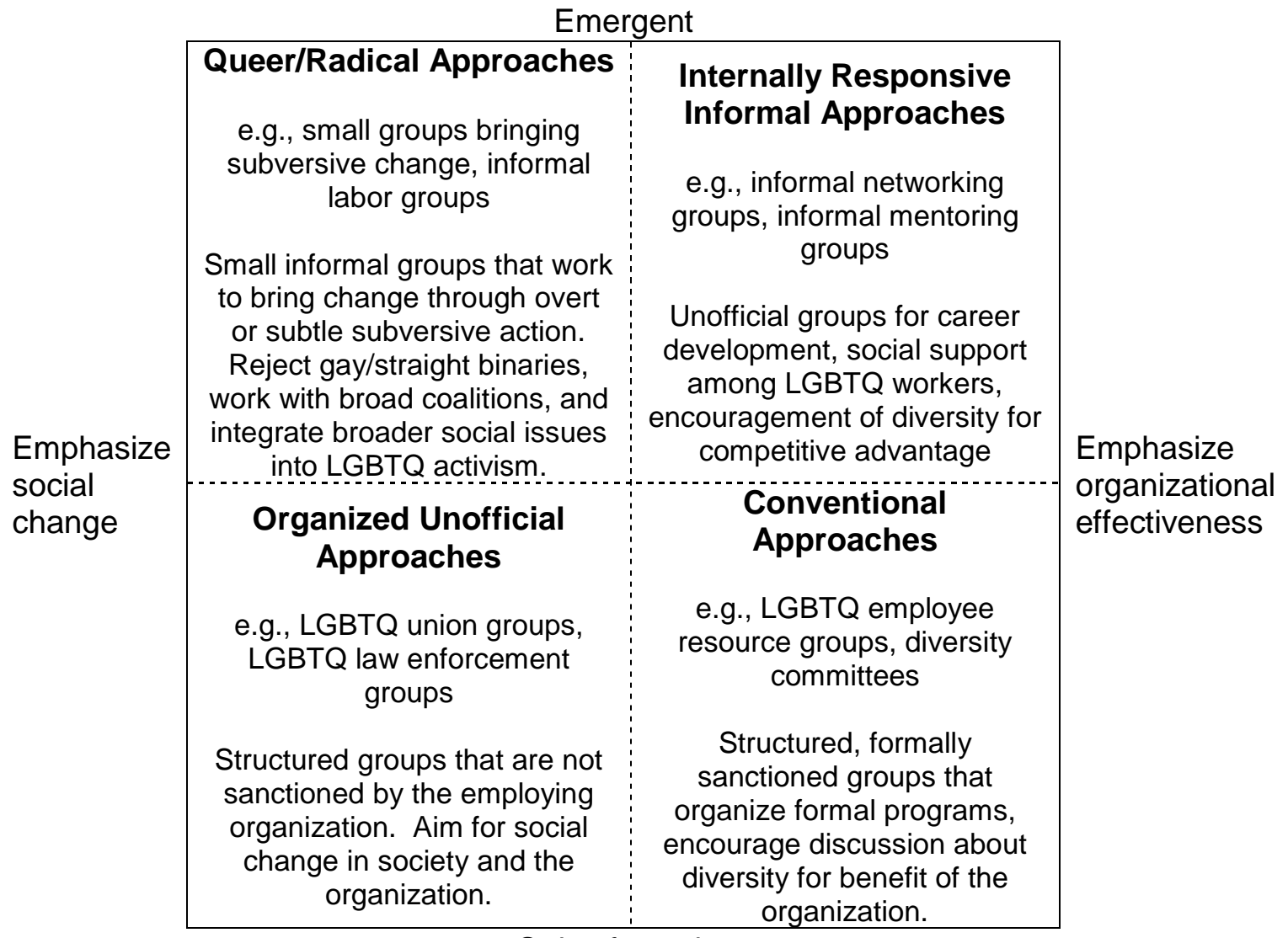

Strive for order

Figure 1. Approaches to viewing LGBTQ employee groups.

\section{LGBTQ Organizing Strategies}

I explore the differences between queer and identity-based approaches to organizing around sexuality. Identity politics is "a wide range of political activity and theorizing founded in the shared experiences of injustice of members of certain social groups" (Heyes, 2002, para. 1). The classic debate over identity politics is familiar to many social and ethnic movements and is especially well known within LGBTQ circles. The debate centers around whether members of a socially constructed group choose to adopt a fixed identity in order to gain political power or whether they reject the fixed identity because of the limiting nature of defined identities 
(Gamson, 1995). For LGBT people, much of the social change that has occurred can be credited to the adoption of an ethnic-type gay and lesbian identity by those who have sex with members of the same gender (D'Emilio \& Freedman, 1997).

Queer theory and queer politics, on the other hand, has provided an alternative to the identity-based approaches embraced by some in LGBT politics. "Queer" is a contested word and has multiple meanings in various settings. By adopting a deconstructionist approach, queer theory rejects fixed categories (e.g., "lesbians") and the idea that leaders of a movement can speak for its members. At its core, queer theory rejects notions of sexual identity and instead emphasizes the fluidity of human sexuality. Queer approaches are more open and inclusive, which can lead to opening conversations with others rather than shutting people off into ghettoized categories (Alexander, 1999; Gamson, 1995; Sedgwick, 1990). This opening of conversations is possible due to the expansive nature of queerness and the lack of focus on narrow, insular concerns.

There is a possibility for utilizing and recognizing both the queer and identity approaches (Gamson, 1995). Alexander (1999) contends that identity cannot be eliminated; however, he calls for an emphasis on shared values that LGBTQ people have in common with others. Through emphasizing these shared values, partnerships and larger constituencies can emerge. He provides the Religious Right as an example of emphasizing shared values. Within the Religious Right, there are great differences on specific theological issues. They have strategically underemphasized (but not ignored) their theological differences and have rallied around shared values, which has resulted in an extraordinarily powerful movement. For LGBTQ employee groups, there are opportunities for joining forces with other groups on issues like domestic partner benefits for unmarried couples (not just for same-gender couples).

\section{Setting}

This study occurs within two primary organizations: one is a large institution and the other is a loose-knit coalition of activists. Most events occurred among trustees, administrators, employees, and students from the University of Illinois (U of I). The U of I Ad-Hoc Domestic Partner Benefits Task Force was the other organizational setting in the study.

The U of I is the state's largest university system, with three main physical campuses which will referred to in this article as UIC (University of Illinois at Chicago) UIUC (University of Illinois at Urbana Champaign, and UIS (University of Illinois at Springfield). The governor appoints nine of the board members to six-year terms, in addition there are three elected student members (one of which is appointed by the governor each year to have full voting privileges). The university has a President and each of the three campuses has a Chancellor.

\section{Methods}

Because this project addresses a bounded phenomenon and explores the intricacies of a single long-term effort, I utilized case study methodology (Stake, 1995). The focus is on narrative description and interpretation of the case, its actors, and the issues identified for investigation. A major focus of this work is to recount the past processes to attain equitable benefits in the university; therefore I also draw upon historical research methods (Davidson \& Lytle, 1992). In this recounting, I was continuously confronted with the goal to challenge what might seem apparent at first glance and to be skeptical. I attempted to continue seeking the truth and interrogating my own preconceptions while understanding that the account I present is not the absolute truth. 
The research question was explored through examining the approaches to organization development and change and LGBTQ organizing. Throughout the data collection process, I relied on three basic types of data. Anderson, Herr, and Nihlen (1994) explain that data can be gathered through: (a) talking with people (either orally or through surveys), (b) examining artifacts, (c) reflecting in journals (by the researcher), and (d) observing people.

I interviewed 21 individuals who had been involved in the DPB effort since it started in the 1980s (two of the individuals were interviewed twice). I spoke with activists, administrators, and a member of the Board of Trustees who were involved in this process. These interviews occurred at all three campuses and via telephone for those no longer in the state. I used a semistructured interview guide approach (Patton, 2002). When participants consented, the interviews were recorded and transcribed. Records such as university reports, internal memos, policy drafts, newspaper articles, committee minutes, and other materials and correspondence were examined. Additionally, resources were obtained online through various university websites. An invaluable resource was the archive of the "uidpbenefits" listserv, used for communication between members of the three-campus group, containing 318 messages. Lastly, I used journaling to record my ongoing insights, recollections and opinions and observations about theories in practice (Hobson, 2001).

Table 1

Individuals Interviewed or Mentioned in Study

\begin{tabular}{|c|c|c|c|c|c|}
\hline Pseudonym & University Title & Campus & $\begin{array}{l}\text { Retired/ } \\
\text { Resigned } \\
\text { at Time } \\
\text { of Study }\end{array}$ & $\begin{array}{l}\text { Disclosed } \\
\text { as } \\
\text { LGBTQ }\end{array}$ & Interviewed \\
\hline Blair, Rick & $\begin{array}{l}\text { High-level } \\
\text { Administrator** }\end{array}$ & $\begin{array}{l}\text { UIUC/U } \\
\text { of I } \\
\text { System** }\end{array}$ & No & Yes & Yes \\
\hline Brady, Chris & $\begin{array}{l}\text { Director of GLBT } \\
\text { Concerns }\end{array}$ & UIC & No & Yes & Yes \\
\hline Campos, Eduardo & Academic Professional & UIC & No & Yes & Yes \\
\hline Catlay, Jon & Undergraduate Student & UIUC & No & Yes & Yes \\
\hline Stoddard, Craig & $\begin{array}{l}\text { Director of LGBT } \\
\text { Resources }\end{array}$ & UIUC & No & Yes & Yes \\
\hline Emerson, Douglas & $\begin{array}{l}\text { Member, Board of } \\
\text { Trustees }\end{array}$ & $\begin{array}{l}\text { U of I } \\
\text { System }\end{array}$ & No & No & No \\
\hline Fisher, Wayne & $\begin{array}{l}\text { Vice President of } \\
\text { Administration }\end{array}$ & $\begin{array}{l}\text { U of I } \\
\text { System }\end{array}$ & Yes & No & Yes \\
\hline Lynch, Janet & Administrator** & UIUC & No & No & Yes \\
\hline Morland, Linda & Professor & UIS & No & Yes & Yes \\
\hline Mueller, Kathy & Academic Professional & UIC & No & Yes & Yes \\
\hline Murphy, Ann & Academic Professional & UIUC & No & Yes & Yes \\
\hline Neely, William & Chancellor/ President** & $\begin{array}{l}\text { UIC/ U of } \\
\text { I } \\
\text { System** }\end{array}$ & Yes & No & Yes \\
\hline
\end{tabular}




\begin{tabular}{|c|c|c|c|c|c|}
\hline Orbell, Elizabeth & Professor & UIUC & Yes & No & No \\
\hline Fitzgerald, Philip & $\begin{array}{l}\text { HR Academic } \\
\text { Professional }\end{array}$ & $\begin{array}{l}\text { U of I } \\
\text { System }\end{array}$ & No & No & Yes \\
\hline Pratt, Kay & Fellow & UIUC & Yes & Yes & Yes \\
\hline Ritter, Todd & $\begin{array}{l}\text { Member, Board of } \\
\text { Trustees }\end{array}$ & $\begin{array}{l}\text { U of I } \\
\text { System }\end{array}$ & No & No & Yes \\
\hline Rozen, Susan & Chancellor & UIUC & Yes & No & Yes \\
\hline Rummel, Evan & President & $\begin{array}{l}\text { U of I } \\
\text { System }\end{array}$ & No & No & No \\
\hline Sauter, Charles & Professor & UIUC & Yes & No & Yes \\
\hline Thorley, Julia & $\begin{array}{l}\text { Secretary of the Board } \\
\text { of Trustees }\end{array}$ & $\begin{array}{l}\text { U of I } \\
\text { System }\end{array}$ & No & No & Yes \\
\hline Weidemann, Dan & Associate Professor & UIC & No & Yes & Yes \\
\hline Wells, Christine & Academic Professional & UIUC & No & Yes & Yes \\
\hline Williams, Judy & Director of HR Policy & $\begin{array}{l}\text { U of I } \\
\text { System }\end{array}$ & No & No & Yes \\
\hline Woodworth, Paul & Administrator & UIUC & No & Yes & Yes \\
\hline
\end{tabular}

* In cases where the title is irrelevant and would risk revealing the participant's identity, I have chosen generic titles such as "Administrator" or "Academic Professional"

** Various positions or campuses during time covered in study

\section{Data Analysis}

Data analysis occurred through narrative description and thematic analysis. Narrative description occurred as a way of recording a history of the events as they occurred, in order to provide a richer understanding to readers (Stake, 1995). A spreadsheet tracked both key events related to DPBs and the larger contextual events affecting this process. Thematic analysis occurred as a result of iteratively reading data, taking notes, compiling narratives, and identifying themes that occurred throughout the analysis. As themes emerged, notes and descriptions were made to capture them. Deductive analysis was used for identifying instances of individual education efforts, specific approaches to organization change, and use of identity politics and queer approaches to organizing. This deductive analysis complemented the inductive analysis, which explored the complexities of these issues. Inductive analysis was aided by Bogdan and Biklen's "family of codes" (as cited in Anderson, et al., 1994), which included setting/context codes, situation codes, participant perspectives, participants' ways of thinking about people and objects, process codes, activity codes, event codes, strategy codes, relationship and social structure codes, and methods codes. This system provided a workable framework for organizing the data as the themes emerged.

\section{Research Quality}

First, by using member checking and having multiple sources and types of data, I sought to minimize any misrepresentation of participants and their experiences. I emailed each interview transcript to participants and asked them to comment or clarify any of their statements. 
The idea of triangulation or crystallization expands on my attempt to minimize any misrepresentation. Like crystals, our research, "depends on how we view it, how we hold it up to the light or not" (Janesick, 2000, p. 392). Various data sources not only allowed for crosschecking, but also allowed for exploration of various truth claims (Brennan \& Noffke, 1997).

In seeking to understand the nearly 20-year process of attaining DPBs, I relied heavily on oral histories. With oral histories, one must continuously be aware of the filtering that occurs by participants (Davidson \& Lytle, 1992). In other words, participants may withhold information, consciously or unconsciously, or present experiences in a certain light. In my case, the activists may have felt more comfortable talking truthfully with me about the inaction of the administration, but may have been less likely to raise important issues about conflict and tension within the group. Additionally, since this issue was ongoing, current administrators and board members (less so for those who have retired) certainly used a certain degree of political cautiousness in addressing the topics. Lastly, detailed memories of events shift over time. To help minimize these issues, I relied on multiple types and sources of data.

\section{Findings}

In this section, I recount the case, by dividing it into meaningful themes that arose during the analysis.

\section{The Early Years}

"The early years... are the most important years in figuring out this whole issue." -William Neely, Former U of I President and UIC Chancellor

The 1980s were a time of great upheaval among LGBTQ communities, with newly found visibility hampered by the AIDS crisis that eliminated a large percentage of the gay male population. However, the AIDS crisis also mobilized the communities to act in concerted efforts around the country (D'Emilio \& Freedman, 1997). At UIUC and UIC, LGBTQ campus organizing increased, accompanied by demands for greater visibility, equitable policies from the university, and an improved climate for LGBTQ students. During those years, DPBs arose very quickly as a significant issue to be addressed.

Due to several incidents, including a gay student being accosted in the student union for wearing fraternity letters from his former school, undergraduates at UIUC organized rallies and protests over the lack of attention to such problems. A group of gays and lesbians met with the Chancellor and as a result of the meeting, he appointed a task force to "investigate the campus climate for gays and lesbians." As a result of that process, a group of staff and faculty called Out on Campus, which existed mainly as a social group, began to advance a political agenda.

According to Paul Woodworth, one of the early leaders of the group, "we were coming in on the coattails" of the undergraduates. This group of employees lobbied for (a) rewording the nondiscrimination statement so that sexual orientation was included with the other characteristics, (b) attaining domestic partner benefits, and (c) establishing an office to support LGBT students, staff, and faculty. At a meeting with the Chancellor, the group presented their goals and another task force was created to address the concerns. As a result, some DPBs were added in the early 1990s, such as access to recreation centers and the ability to use sick time for members of one's household instead of only for spouses and children. Members of the taskforce were told that health insurance benefits could not be changed since the State of Illinois controlled 
those. The group was successful in their request for establishing an Office of LGBT Concerns in 1993 and attained the rewording of the nondiscrimination statement in 1993.

During the late 1980s, the City of Chicago was undergoing significant political volatility. Harold Washington, the city's first African American mayor found himself dealing with a racially polarized city, an entrenched political machine, and a divided city council. According to William Neely, former U of I President and UIC Chancellor, UIC was "a lightening rod." Students and faculty "go back to their communities, and they bring to the university the values of their communities. All of these diverse groups convene on the university and expect action from the administration."

In his previous role as Vice Chancellor for Academic Affairs, Neely instituted "status committees" with names such as "Committee on the Status of Blacks" and "Committee on the Status of Lesbian, Gay, and Bisexual Issues." He started these committees in response to demands by these various communities, to provide an interface with the administration, to provide advice to administrators, and to provide a "relief valve" when problems arose.

In 1993, the committee submitted a "Position Paper on Same-Sex Domestic Partnership" to the Chancellor. The paper outlined the rationale for implementing DPBs, which was that discriminatory benefits policies violated the university nondiscrimination policy and the city's nondiscrimination ordinance. The paper outlined "Easily Changed Policies," "Group Health Insurance," and "Death and Survivor's Benefit," in which sample policy language was provided, along with sample policies from peer universities. Some "easily changed policies," such as access to recreation facilities, began to change following submission of the position paper. However, progress on health insurance was much slower. Neely contended that the group needed the approval of the Senate to move the issue forward.

Following the advice of the Chancellor, the UIC group began organizing to gain approval for a non-binding resolution supporting same-sex DPBs in the Senate, a body of faculty, students, and academic professionals. After approval was gained at UIC, a similar resolution was approved by the Senates at UIUC and UIS. The approval process at UIC was quite complicated because after a couple of years of delays by senate leaders and committees, activists bi-passed those mechanisms and called for a floor vote after lobbying individual senators directly. After contentious debate, the resolution passed by a narrow margin on April 25, 1995. After the vote, Dan Weidemann reported hostility and anger from the leadership over he and the group bypassing the accepted protocols to gain approval. Several days after the vote, a member of the Senate leadership was in an elevator with Dan and "shook his finger at [him] and said, "we will not forget this.",

After passage of the resolution, the UIC group asked the Chancellor when the issue would move forward. He said he would express it to the President, but added that the issue needed support of the other two campuses as well. Shortly thereafter, in August 1995, Chancellor Neely became President of the entire university system. UIC activists perceived that the LGBTQ activists in Urbana were focusing on other issues and DPBs were not a high priority. The UIC group organized a forum in Urbana about DPBs, in conjunction with the activists in Urbana.

After the forum, Urbana staff and faculty organized around the issue and lobbied senators to move the issue through the Urbana Senate, where it moved through the accepted channels. Dan Weidemann from Chicago perceived that women's groups on the Urbana campus were much more willing to work for passage than they were at UIC. After the resolution slowly worked its way through committees, it was scheduled for a vote. Paul, an academic professional, 
recounted that the group contacted faculty senators known to be supportive in order to ensure they were attending the meeting when the vote occurred. The resolution passed overwhelmingly on September 30, 1996.

Opposite-sex partner benefits. The discussion over whether LGBTQ activists should pursue DPBs for both same-sex and unmarried opposite-sex partners arose very early at UIC. The activists were open to including opposite-sex partners, but their "agenda was same-sex benefits," according to Dan Weidemann. This focus resulted from a lack of work on the part of other groups to attain opposite-sex benefits. In particular, the UIC Chancellor's Committee on the Status of Women, was rhetorically supportive, but not willing to put the labor in to work for passage.

When the issue was brought to Urbana, Paul Woodworth explained that people asked why the policy was exclusively focused on same-sex partners since "some prominent faculty were not married but were living with an opposite-sex partner." As a result, the resolution was broadened and the successful resolution included domestic partner benefits for both same-sex and opposite-sex partners.

The successful UIS resolution also included opposite-sex partners. Two years after the contentious vote in the UIC Senate, an updated resolution passed on December 13, 1997, which included same and opposite-sex partners. On January 22, 1998, the University Senates Conference, with representatives from all three campuses, approved the resolution and passed it on to President Neely.

Building lasting structures. During these early years of organizing around DPBs, LGBTQ students, staff, and faculty attained a newfound visibility and voice on the U of I campuses. Chancellor Neely was quite committed to collaborating with constituent groups and working through the governance process. He formed and provided committees with budgets that enabled these groups to organize sustaining structures. Dan Weidemann explained that these structures gave legitimacy to the actions of the group, which gave them more of a voice and allowed staff members to justify using working hours to engage in these organizational changes.

The structures at UIC enabled consistent and relatively well-organized LGBTQ activism, spanning over 20 years. In contrast, LGBTQ activism at Urbana was more sporadic, less organized, and more grassroots-oriented, especially when looking at the DPB issue.

The sensitive but cautious chancellor. UIC Chancellor and System President William Neely was confronted with the DPB issue for almost 20 years. Neely, who earned his master's and Ph.D. from UIUC, later became a faculty member and administrator at UIUC. After living in Urbana since 1961, he accepted the position of Graduate College Dean at UIC in 1985. In speaking with me, he explained the transformation that resulted from moving to UIC:

My kids were raised [in Urbana]. We were embedded in that environment. And then all of a sudden we moved up to Chicago and we had never lived in an urban area before. .... To give you some sort of idea on how my perspective personally changed, I came up here in August of '85, and I'm here for three or four months. And I go back to Urbana for the first time. In the Union, I walk up those stairs and walk outside, and all I see is white. All I see is white. And I thought to myself, my goodness, this is, I can imagine what a minority would feel like, walking up out there and seeing nothing but this white. .... If I had not come here and I stayed in Urbana and I had risen to some sort of position where 
you had to deal with these issues, I'd expect my actions might have been different.

This personal transformation and sensitivity that arose from being placed in a diverse environment resulted in the development of an acute appreciation for the issues dealt with by LGBTQ students, staff, and faculty.

Neely explained that through his interaction with the Chancellor's committee, he was educated on LGBTQ issues and the real problems that can result from the lack of DPBs. In discussing his ultimate support of same-sex DPBs and not DPBs for unmarried opposite-sex couples, he explained the injustice because of heterosexuals "coming and going [in and out of marriage] and having all these benefits, and yet there are committed relationships in the gay community that are absolutely beautiful relationships. And they got nothing. And I thought that's just unfair. It's an unfair issue."

He embraced an extremely slow, deliberate process in which he cautiously considered political issues with the State Legislature and the Board of Trustees. Much of his progress on this issue resulted from working through shared governance and formal advisory committees. He was widely considered as a sincere advocate of shared governance.

As Chancellor, Neely pressed the LGBT Status Committee to work with the Senate in moving the issue forward before he would make much of an effort. After becoming President, he continued to insist upon this deliberative process. Although it does appear that he was stalling to wait for the larger political climate to become more amicable to DPBs, the evidence also suggests that he had a sincere commitment to deliberative processes.

\section{Pressuring the Administration}

"[President William Neely] is our ally not our savior."

- Ann Murphy, Activist from Urbana (in an email to other activists in 2002)

"It was always administrators who were the roadblock."

- Chris Brady, Director, Office of GLBT Concerns at UIC

After the Senates Conference approved the resolution supporting DPBs in January 1998, the decision of whether to move forward on the benefits rested with the administration. For over four and a half years, the issue sat at the administration level. During this period, activist interest fluctuated. The DPB movement finally gained new momentum in 2000, which continued through the initial passage of rudimentary DPBs in 2003.

Stalling. On April 16, 1998, President William Neely sent a letter to the chair of the University Senates Conference, providing the details of the University Counsel's legal arguments against offering DPBs. The argument's first point was that the State could not provide DPBs to university employees because it is forbidden under state law. At the $\mathrm{U}$ of I, health and dental benefits are provided by a state agency rather than through a university vendor. Some advocates argued that the university could determine who was eligible for these state benefits. The administration countered by arguing that the state law defined "spouse" as a legal wife or husband.

After the President shared the legal opinion with the chair of the University Senates Conference, the chair of the Equal Opportunity Committee of the Urbana Senate asked two professors in the College of Law to prepare a separate legal opinion regarding this issue. Issued 
on April 27, 1998, their legal opinion countered the University Counsel's opinion. Regarding the University Counsel's concerns about being sued, they countered that no public university in the nation had been sued for offering DPBs; however, universities had failed to prevail in lawsuits because of not offering DPBs. As part of an effort to increase public dialogue on the issue, the memo from the law professors was given to the press, resulting in an article in the local newspaper in Champaign-Urbana on May 1, 1998.

Charles Sauter, a member of the Senates Conference at the time, explained to me that "Neely was obviously stonewalling, with the notion that since he got a legal opinion he couldn't do it." Sauter, who was not an active supporter of DPBs, explained, "Neely had large-scale goals to accomplish, "a little issue like domestic partner benefits can screw a lot of things up." Neely apparently felt that the time was not right to act on the issue. The State Senate and Governor's offices were controlled by Republicans. According to Neely, Wayne Fisher (former U of I Vice President for Administration), and others, the President of the Illinois State Senate was vehemently opposed to DPBs. This same Senate President successfully fought a bill for years that would have expanded the statewide non-discrimination act to include sexual orientation and gender identity, even though the House passed the bill repeatedly and the Republican governor promised to sign it.

Given this difficult external environment, the contradictory legal opinions about the university offering DPBs allowed Neely to delay action on the issue. In recounting those years, Neely explained, "The legislature was not at all supportive. It was a Republican controlled legislature with strong leadership, and a leadership who really, really did not have any sympathy for gay, lesbian, and bisexual issues. Quite the opposite. .... Attitudes like, 'Over my dead body this is going to happen."”

A revealing piece of correspondence provided evidence of the possibility that the administration had determined it would stall on this issue. Shortly after the Urbana Senate vote, a woman who was a "major university donor," former member of the Board of Trustees from the 1970s, and former member of the state Human Rights Commission wrote a letter to the Urbana Chancellor stating that the university should not "further diminish the meaning of family by granting benefits to whomever is roaming in at the moment." The Urbana Chancellor responded by explaining, "...the campus administration does not control the issues taken up by the Senate...nor the outcome of its votes. Often, I wish we did." In this letter, written over a year before the University Counsel's issuance of a legal opinion on the matter, the Chancellor goes on to state, "Decisions about employee health benefits are made by [the] state agency [that controls benefits]." From the letter, one could assume that the administration had already formed its opinion on how to approach this delicate political issue, regardless of what the Senates wanted.

Building coalitions. After the administration's legal decision was announced, momentum slowed on the DPB issue for a couple of years. However, in 2000, a small group of advocates started working with a group of Urbana academic professionals seeking unionization through an affiliate of the National Education Association. As part of this effort, DPBs were raised by LGBTQ and ally members of the Association of Academic Professionals (AAP). Christine Wells, a counselor from UIUC, organized an expanded AAP effort in April 2001 to press for these benefits. DPBs were used as an organizing strategy for the AAP and the AAP served as a platform from which LGBTQ staff could lobby for DPBs

The AAP distributed signature cards throughout the campus in which people signed to indicate their support for DPBs. These AAP cards were later used on the UIC campus. The 
cards were presented to trustees during Christine's public comments at a board meeting. In addition to indicating widespread support to trustees, the process of collecting signatures also allowed for members of the campus community to be educated on the issue. Additionally, the AAP name was on each of the cards, providing visibility for the union, which was seeking to organize workers. The AAP provided a valuable platform from which the profile of the DPB issue could be raised significantly, but the broad-based queer coalition may not have been as strong as it appeared because Christine was the main person doing the DPB work from within this supportive union.

Working through formal and informal structures. During this period, pressure was applied by LGBTQ employees and students through the formal university power mechanisms (e.g., the Campus Senates) and through new grassroots efforts (e.g., three-campus task forces). In the end, both approaches resulted in effectively pressuring the university to act. A formal structure like the Senate cannot focus exclusively on an issue like DPBs, but the grassroots task force (although it had no official authority or standing), focused its efforts on DPBs from 2002 through 2009.

Persistent pressure from the senates. The Urbana Senate relentlessly pressured the administration to provide DPBs. After passing the original resolution in 1996, the Senate Council asked the Senate Committee on Equal Opportunity to gather further evidence and support for DPBs when they officially resurrected the issue in November 2000. This resurrection occurred after President Neely issued another statement to the University Senates Conference on October 12, 2000 denying their request for DPBs. The committee's information summarized the offering of DPBs by other universities, corporations, and state/local governments and was presented to President Neely in a meeting on January 29, 2001. On April 23, 2001, the Urbana Senate approved, by voice vote, a new resolution supporting DPBs for university employees.

The UIS Senate voted in favor of a similar repeat resolution on September 14, 2001. On November 14, 2001, the University Senates Conference (from all three campuses) reiterated its support for DPBs. Much of the pressure from the individual Senates and the Senates Conference resulted from LGBTQ individuals pressuring Senate leaders, allies pressing the issue, and supporters of opposite-sex DPBs advocating for a broadly inclusive benefit program.

Three-campus task force. Chris Brady was hired as the full-time director of the Office of GLBT Concerns at UIC in November 2000. Immediately after starting in the position, employees asked him what he was doing to help secure DPBs. As a result, he organized a new group that came together at UIC in February 2001 to help secure the benefits. Around the same time, an undergraduate student at UIUC, Jon Catlay, became known as a very effective LGBTQ organizer on the campus. He took on the DPB issue as one of his goals and sought to bring the three campuses together again to work on the issue. In coordination with Chris at UIC and Linda Morland at UIS, he organized a meeting in Urbana for concerned employees and students from all three campuses on February 22, 2002. As a result of that meeting, a listserv was created, along with a call for additional work at the three campuses. During the meeting, the group decided to have the directors from the UIC and UIUC campus LGBT offices, along with Linda Morland, request a meeting with President William Neely, which was held on April 12, 2002. The three-campus activist meeting at Urbana resulted in the lasting, informal coalition that continued when this research concluded. 
The social justice chancellor. While momentum and impatience had been building for months about DPBs, another major factor entered the university on August 1, 2001. Susan Rozen became the first female Chancellor at Urbana and was known as a champion of diversity and social justice. In her last position as provost at a major research university, she became known as a defender of affirmative action, while facing a highly publicized lawsuit. LGBTQ students, staff, and faculty saw an opportunity to work with her in making positive changes to the campus. As an example of her commitment to diversity, within her first year in office, Rozen agreed to form a standing Chancellor's Committee on LGBT Issues.

Rozen also asked the Urbana HR department to compile a report for the Board of Trustees in January 2002, explaining the rationale for offering DPBs. The report was officially issued to campus administration, but Rozen told me that the intended audience was the Board of Trustees. Janet Lynch, who worked in HR, compiled the report. Janet served as chair of the original 1987 UIUC task force on sexual orientation while working as a health educator. The report was widely credited with moving the issue to a new level of legitimacy.

Within a few months after the main DPB issues were resolved, Rozen left the University after a failed effort to eliminate the Native American (Chief) mascot at UIUC. In my conversations with administrators, it was apparent that any recollection of Rozen's actions on DPBs were colored by her "deep, deep involvement in the first effort to eliminate the Chief" A participant engaged in campus governance (not connected with the LGBTQ movement) said, "She was a complete and total disaster for the campus." However, LGBTQ participants, those who worked closely with her, and those with a strong connection to social justice causes generally remembered Rozen quite fondly.

Efforts toward organizational change. As a result of the persistent pressure from the Senates, the work of the activists, and the support of Susan Rozen, it became clear that the DPB issue had a good chance of being presented to the Board of Trustees. Activists and advocates targeted their education and pressure efforts toward the upper administration, the Board of Trustees, and the broader community. The approaches to these efforts, along with the debates on who/how to educate, provide a glimpse into the activists' and administrators' approaches to organizational change, social organizing, and education.

The official campus report. In January 2002, Janet Lynch in the Urbana HR office prepared a report about DPBs for the Board. Janet focused on peer universities and called her counterparts at those universities to obtain information about the costs of implementing the benefits and to obtain sample policies. Also included was a complete list of all universities and Fortune 500 companies offering DPBs. Additionally, she provided a transcript from the meeting where the Indiana University Board unanimously approved DPBs. Indiana's passage of the benefits was repeatedly mentioned in interviews as a major turning point because of its proximity to Illinois and since most people saw that state as being much less progressive than Illinois.

Do we need a leader? As mentioned earlier, the UIUC LGBTQ efforts had much less structure than at UIC. Interview participants consistently acknowledged that the campuses differed in these orientations. Since Chris Brady started at UIC in 2000, he served as the consistent leader for DPBs on that campus. However, when asked who emerged as leaders of the Urbana efforts and the three-campus effort, responses varied. For example, Christine Wells from UIUC, explained,

It was sort of like terrorist cells. We were all operating sort of a little bit differently. I know it's a terrible metaphor, but it really was sort of a differently organized effort. 
Maybe if we had been organized differently, it would have happened sooner.

On the other hand, Ann Murphy, also from UIUC, saw herself as leading the grassroots effort on that campus and Rick Blair as "leading from the administration's point of view." However, she acknowledged that leadership was much more allusive at UIUC. At the three-campus level, after Jon Catlay graduated, Chris Brady and Linda Morland consistently provided leadership in keeping the three-campus effort going.

As a result of the contentious debate among these leaders in how to work with President Neely, however, the group became more grassroots focused. Leadership emerged from multiple levels and clear centralized leadership did not re-emerge until after the initial passage of DPBs, when widespread interest waned and bureaucratic details needed refinement.

\section{Proposing It to the Board}

"It was a trial balloon to see what was going to happen. You throw up the balloon and see who fires at it. And sometimes you're surprised. Sometimes you have advocates that you would never think you'd have, and advocates sometimes become enemies."

- William Neely, former University of Illinois President

During the April 22, 2002 meeting with campus advocates, William Neely acknowledged his intentions of raising the issue of DPBs during the Board of Trustees' July meeting. In the interim, activists continued working on the issue and speaking during Board of Trustees meetings.

The trial balloon. With the anti-gay rights Republican State Senate President still in office, President William Neely told the Board of Trustees he intended to propose DPBs for same-sex couples. In the July 1, 2002 memo, he provided the legal, competitive, and employee relations rationale for offering the benefits. Consistent with Neely's steady, deliberate style, it appears he had no intentions of moving this issue quickly, even after he indicated his intention of raising the issue to the board. However, he recognized the impatience of the LGBTQ activists in his conversation with me:

From the beginning you're always trial ballooning it. You're trial ballooning it with your colleagues on campus. You're trial ballooning it with the Board members. .... It was not an assault. And again, it was subtle. Eventually things came together. But the trick was, dealing with the impatience in the gay communities. I mean, they appeared to trust us. But they were saying, "come on, we've been at this for a long time, and you're being supportive of it, but nothing's happening. Nothing's happening." But in the end, I think there was trust. And so things worked out.

A primary goal of the "trial balloon" was to test the reaction of the State Senate and the Senate President.

Complicated relationship with the state. In private conversations with stakeholders, William Neely indicated his support for moving forward on DPBs nearly a year before the Democratic sweep of state government. I asked Neely why he felt comfortable proposing the benefits while Republicans were still in power. He indicated that it was a trial balloon and that he felt sensibilities had progressed so that DPBs were considered much less controversial. Lastly, he explained that the LGBTQ community was becoming impatient and he felt that he 
needed to finally move on this issue. When asked if there was one impetus that resulted in his decision, he explained:

It was probably just reading the environment. You know, a lot of these things are intuitive. You get a sense of things, and a little voice in my head or a little bell goes off, that kind of tells me that, you know, now is the time we can do something. In a lot of areas. All these big decisions that you make are never cut and dried. It's a matter of looking at all the factors and kind of just making adjustments.

In considering the U of I's relationship with the state, it is important to note that Neely served as President during a period of significant declines in state funding for higher education. When Neely initially raised the DPB proposal to the board, members had just learned that the university faced a $\$ 25$ million cut in operating expenses from the state. These budget problems resulted in layoffs and program cuts during the period in which DPBs were being considered. At the same board meeting where DPBs were proposed, the university announced that 900 positions would be eliminated throughout the U of I system (mostly through attrition) while hundreds of course sections would be eliminated. In conversations with university leaders, fear of retribution from state government served as a major obstacle in offering DPBs.

Faculty presentation. In introducing DPBs to the Board of Trustees, Neely briefly introduced the issue and explained that the Campus Senates and the Senates Conference asked him to advance the issue to the board. He explained that he would bring a recommendation to the board for same-sex DPBs in future months. Neely asked Elizabeth Orbell, a member of the University Senates Conference and UIUC faculty member, to give a presentation to the Board of Trustees on the issue. Julia Thorley, longtime Secretary of the Board and a university officer, explained that it was somewhat unusual for the President to ask a faculty member to give such a presentation. However, since the University Senates Conference had been a major player in pushing for the benefits, Neely felt it was important to give them a voice.

Following the presentation, trustees engaged in conversation about the costs of the benefits and implications with the state. The University Counsel made a case for the legality of the benefits, based on recent court decisions.

The unlikely opponent. Douglas Emerson, a long-time member of the Board of Trustees, emerged as the primary opponent of DPBs. Wayne Fisher explained, "He was a surprise to many people, because that individual trustee generally is very interested in policies that would make the institution more competitive, etc., etc., etc." Emerson took both public and behind-thescenes actions to defeat the proposal.

On the board agenda for November 14, 2002, William Neely included a proposal for a program that would reimburse employees with same-sex partners for the premiums of insurance purchased directly from insurance companies. Early in the meeting, Emerson asked that the DPB proposal be removed from the agenda and considered at a later meeting. He said the new state legislature should be given an opportunity to consider the issue for all state employees. All but two board members approved the removal of the agenda item. At this point, it appeared that the trial balloon had been shot down.

Crisis among the activists. Among those working to attain DPBs, multiple crises and disagreements happened after Neely proposed same-sex only benefits, after he proposed a reimbursement scheme instead of full DPBs, and after Emerson seemingly killed the DPB policy. 
Insufficient benefits. A controversial issue for the group was President Neely's November 2002 board proposal that the university not actually offer insurance benefits directly to same-sex partners. Instead, the university would offer an insurance premium reimbursement program since the university failed to find an insurance company interested in offering a separate insurance program for domestic partners of $U$ of I employees. Several problems existed with this approach. First, partners would be responsible for purchasing their own insurance. Those with prior medical conditions would have difficulty finding individual health insurance. Second, individual health insurance is much more expensive than group insurance. The administration proposed a mere reimbursement up to the university's cost of offering group insurance for dependents. When this information was uncovered on November 11, 2002, just days before the November $14^{\text {th }}$ board meeting, multiple messages on the group listerv indicated frustration over the lack of communication from the administration regarding this significant change. Although group members appeared poised to oppose the proposal, Ann Murphy organized an "emergency meeting," in which Rick Blair and the UIUC HR Director explained the details of the proposal and persuaded the group to support it as an incremental step toward more adequate benefits. After Ann Murphy and Jon Catlay reported on the meeting, members from the other campuses generally agreed that this interim step should be sought.

The public campaign. After the President's DPB proposal was removed from the board agenda on November $14^{\text {th }}$, Chris Brady (UIC Director of GLBT Concerns), organized a protest at UIC to "show disappointment to the Board of Trustees" and to show that "we expect to be recognized for the job we do and how well we do it." Including representatives from the press, Dan Weidemann said that 80 people attended the event. Although previously supporting only behind-the-scenes efforts of President Neely, both Chris and Dan became supportive of more aggressive tactics after the board delayed the vote.

At the February 2003 Board of Trustees meeting, the UIC group organized an early morning gathering on a cold morning in which over 50 people held signs in support of DPBs. The organizers used a Valentine's Day theme in which signs said "Be My Domestic Partner Provider" and "Respect My Love, Too." Additionally, UIUC activists delivered hundreds of valentine's cards to board members. Activists were especially hopeful for educating three new board members, who were appointed two days before the meeting, by the new Democratic governor.

After the meeting in which Trustee Emerson read his "consensus statement," effectively killing DPBs, activists met in Chicago to discuss the next steps. After the meeting, Chris Brady summarized the plan as focusing on (a) educating new board members, (b) seeking a plaintiff for a lawsuit, (c) hosting education tables in the student unions at UIC, (d) developing a documentary video, (e) compiling a list of faculty who left the university over the lack of DPBs, and (f) continuing to speak at board meetings.

The new trustee makes it happen. Todd Ritter, a personal injury lawyer, was one of several new board members appointed before the February 2003 meeting. Trustee Ritter's first exposure to the $\mathrm{U}$ of I DPB issue came as a result of multiple public comments during his first board meeting. After these comments, Ritter wanted to know why the university was not offering the benefits. No activists or administrators had contacted him about the issue at that point. He explained to me that if the university continued to not offer these benefits, it was "nothing short of discrimination." As a new board member, Ritter contacted each of his colleagues to gain support for the proposal. Board Secretary Julia Thorley explained that new 
board members rarely advocate for controversial measures after first joining the board. University administrators widely credited Todd Ritter's efforts with the benefits proposal finally being approved.

On the day of the vote, Trustee Ritter gave a speech about the issue, explaining that "it's a matter of civil rights, it's a matter of fundamental fairness," costs are minimal, Fortune 500 companies and other organizations offer DPBs, and that the university should not wait for the state to act on the matter. President Neely also gave a speech supporting the issue. Next, Trustee Emerson gave an "impassioned speech against" the proposal. He started by saying that questions of morality did not come into his decision, but that he disagreed with cost estimates and that the university could not incur any additional costs at that point. Another Republican trustee said that, "This is not condoning a lifestyle. This comes from the oldest member of the board, whose generation was very judgmental. We have to remove our own personal feelings from the facts." Two other board members spoke in favor of the benefits. In his closing comments Trustee Ritter said, "civil rights are priceless, regardless of the cost." Trustee Emerson, who successfully delayed the proposal for months, defended himself by saying that he was in favor of civil rights, which were not the issue being addressed in this vote.

Over ten years after $U$ of I activists first sought health benefits for same-sex domestic partners, the Board of Trustees approved them on July 17, 2003, with all but two trustees voting in favor. The university promised to implement the program as early as the fall. When asked to recall negative response after the board approved the benefits, Neely said, "I don't remember spending any amount of time in terms of damage control. I mean, what's done is done." Other administrators recalled little backlash against the issue.

The governor provides state benefits. For three years, same-sex partners of employees had access to a reimbursement program when purchasing benefits on the private market. In May 2006, after the new contract for the American Federation of State, County and Municipal Employees (AFSCME) included same-sex partner benefits, the Democratic governor issued an administrative order that provided insurance benefits for all same-sex partners of employees in agencies that reported to him. This administrative order covered non-union employees as well. As part of this move, the state agency that provided benefits to state workers allowed state universities to provide same-sex DPBs if they opted to participate. The university quickly announced that beginning July 1, 2006, same-sex partners of employees could enroll in the state insurance program. This victory was won primarily by AFSCME, not by $U$ of I activists or administrators. This monumental change allowed $U$ of I employees to add their domestic partners to the state insurance program for the first time.

\section{Discussion}

To understand the process for employee groups bringing about LGBTQ-friendly changes in the university, I explored the nearly 20 -year effort to attain fully equitable DPBs at the University of Illinois ( $U$ of I). This case study investigated the intricate details of that process within the U of I, but the work can also be connected these ideas to larger conclusions that may apply to other groups seeking similar workplace changes elsewhere. Additionally, I sought to build upon past research in HRD and research dealing with LGBTQ workplace change. 


\section{Employee-Initiated Organization Development in a University}

The efforts to attain equitable DPBs have been focused on very tangible, concrete goals. However, this movement existed within a larger organizational change effort aimed at improving the climate for LGBTQ employees and students throughout the university system. When considering theoretical foundations for such an effort, conventional models of organization development and change fail to recognize the socially-oriented, highly participative, and decentralized structures of universities (Torraco \& Hoover, 2005) and give little attention to issues of power or cultural critique (e.g., Cummings \& Worley, 2005). These power and cultural issues are central to efforts aimed at addressing diversity and difference. Newer organization development models, like the one introduced by Bierema (2010), provide a more relevant framework for considering change as facilitated by LGBTQ employee groups. Bierema's model presents organizational change as occurring through (a) "understanding the context," (b) "critiquing the influences on the issue" through cultural analysis, values identification, and understanding power relations, and (c) "learning through action and reflection." When considering the use of such a model by activists in this study, an ongoing focus on cultural critique allowed queer approaches to be debated among group members. Members may not have been consciously addressing "queer ideas," but as an implicit theory in use (Schön, 1987), this process of cultural critique was one of the most contentious and productive parts of the change process. Members were widely divided at times about the role that administrators should have in "helping" LGBTQ people and whether expansive queer ideas should be incorporated into the coalitional goals.

In considering Bierema's (2010) model of organization development, I conclude that the university environment provided an ideal location for bringing in issues of cultural critique and power as the group members debated and explored these issues through a three-campus effort. The integration of these issues into the discussions and activities of the group resulted in both creative energy and contention, which one of the most cautious group members described as being productive to the goals of the group. I could say the group struggled continuously to balance the competing need for order and the need to embrace chaos (Burrell \& Morgan, 1979).

Some of those working for DPBs saw various "cells" or arms of the group working in loose association. In other words, they would not even see themselves as working in one "organization" that struggled with these issues. In that sense, it may be helpful to stress that individuals or cells within an effort could have differing orientations, when considering my model of LGBTQ employee groups. As I discuss later in considering that model, it is difficult to classify this effort into one of those four categories I proposed, particularly in the period prior to the Board of Trustees approving DPBs.

When comparing this study to Raeburn's (2004) extensive study of conventional employee groups attaining DPBs in corporations, this case study adds to her work by helping us to understand how LGBTQ-friendly changes were attained in a public university setting. In Raeburn's study, corporations moved relatively quickly in adopting benefits after employee groups began requesting them, especially in the later part of the 1990s. Although pressure from employees nearly always contributes to approval of DPBs, I argue that this relentless pressure was more necessary in a university environment. Universities are under constant scrutiny from multiple types of stakeholders (Torraco \& Hoover, 2005). As institutions of higher learning, they historically encourage or at least tolerate free thinking and dissent. This tolerance provides LGBTQ people with a platform from which they can advocate for their issues with less risk than in other types of employing organizations. However, due to the many social issues being raised 
at any given time, an issue like DPBs can easily be forgotten without continuous and strategic pressure from activists. In corporations, social issues are raised in more controlled and contained ways.

The university was very slow to implement DPBs because the State of Illinois provided the majority of employee benefits and the $U$ of I administration preferred to remove itself from benefits discussions, due to political considerations and union bargaining reasons. In contrast, corporations control their own benefits and often seek improvements to "soft" benefits, as an inexpensive way of keeping employees happy. These differing employee relations orientations may help us understand why large corporations have lead the public sector and public universities in adopting equitable benefits (for further discussion, see Githens, 2009; Raeburn, 2004).

\section{Role of Faculty}

Another unique aspect to change in a university setting is the crucial role of faculty support in seeking changes. In the early days of this effort, Chancellor William Neely urged DPB advocates to take their case to the Campus Senates as a first step in moving the process forward. After a contentious start at UIC, faculty members involved in campus and university governance structures provided consistent support to this effort. In an extension of Raeburn's (2004) arguments about the importance of "elite" support in corporations, faculty members at the $\mathrm{U}$ of I were elites who provided support by granting Senate approvals and consistently raised the issue with the President. However, with a couple exceptions, the later stages of approval and refinement of DPBs was orchestrated largely by academic professionals. Some academic professionals, particularly at Urbana, expressed frustration over the imbalance in workload since faculty members were less active in organizing the effort but would occasionally appear at public events or meetings with administrators. Board Secretary Julia Thorley alluded to the need for faculty to provide a public case for the benefits, while staff members were needed for performing behind the scenes work. Such an arrangement may have been effective and may reflect the realities of university life, but it has elitist and exclusionary tendencies that are problematic from an employee relations perspective. If the role of public change agent is limited to faculty members, that practice calls into question the democratic ideals of the university.

\section{Use of Identity and Queerness}

One of the central issues I hoped to illuminate through this study was the tension and interplay between identity politics and queer approaches to organizing. Ultimately, both approaches were utilized, to varying degrees and amid much debate.

Critical HRD and identity politics. Identity politics, combined with critical approaches to HRD, ultimately resulted in the approval of DPBs. Trustee Todd Ritter, who was responsible for persuading his fellow board members to support the policy, was introduced to the issue through the public education efforts of task force members. His motivation for supporting the issue was due to "civil rights" concerns, not over concerns with the inadequacies of the institution of marriage (often used by those who support opposite-sex benefits) or due to competitiveness and economic concerns (often used by administrators).

In this case, critical HRD was practiced by those from throughout the organization, not from those in HR positions in the university. Throughout this nearly 20 -year process, HR largely took a reactive stance and only advocated for the benefits when asked to do so by a Chancellor or 
Vice President. Education and organizational change processes were used to question the status quo in the university through a collective group exercising power by seeking equitable benefits. These identity-oriented approaches, in combination with personal testimonies (discussed below), helped to motivate top administrators and Trustee Todd Ritter in moving the proposal forward.

Coalitions. When considering the use of queerness by advocates of DPBs, three primary queer-influenced coalitional techniques were utilized: (a) working with existing universityrecognized organizations and groups, (b) including opposite-sex couples in DPB proposals, and (c) integrating the push for DPBs into broader social causes.

When attempting to work with existing groups in the early stages of this process, advocates at UIC became frustrated because of a perceived lack of labor from women's groups. As a result, they gave up on the push for opposite-sex benefits. However, the UIUC advocates received more labor and support from coalitional members when compared to UIC, which resulted in long-standing support for both same-sex and opposite-sex DPBs at UIUC. Unlike the Chicago group, the Urbana group had much more active support from the Campus Senate. In the end, the building of coalitions proved fruitful in gaining widespread support for DPBs, but LGBTQ individuals became frustrated in multiple instances over the perceived lack of work by heterosexuals. Repeatedly throughout this study, opposite-sex benefits were linked to involvement from coalitions or from LGBTQ individuals who sought a queer goal of expanding the definition of families through this effort.

Raeburn (2004) found that $64 \%$ of groups with coalition support were successful in attaining DPBs, while only $33 \%$ of those without coalition support succeeded. In this case, the coalition built in Urbana resulted in early successes and widespread support. Opposite-sex partner benefits were appealing to those having philosophical or moral disagreements with the institution of marriage. However, when President Neely began warming up to the idea of DPBs, it became apparent that he would not support opposite-sex benefits. As a result of the UIUC activists' insistence, the DPB advocates continued pressuring for inclusive benefits; however, most members were willing to sacrifice opposite-sex benefits in the end.

In this study, we also saw queer approaches practiced heavily by Jon Catlay, and other student activists at UIUC. In addition to addressing DPBs, they regularly addressed transgender issues and opposite-sex benefits. When considering Duggan's (2003) call for integrating LGBTQ causes into larger economic and social concerns, I saw little evidence of a broad willingness among the DPB activist group to take up other such causes, beyond the efforts of the student activists and the work of Christine Wells through the AAP union. Instead, the group hoped to bring others into advocating for DPBs, but seemed to give little recognition to coalitional members and other supportive organizations.

Despite evidence that non-professional unions are typically interested in DPBs when they include opposite-sex couples (Holcomb, 1999), there was little or no effort to build those bridges with unions, based on the evidence I collected. This type of queer coalition-building allows for expanding the notions of legitimate relationships to include newer family forms that are very common in our society. Interestingly, the AFSCME union for state agency workers ultimately secured state-sponsored DPBs, which trickled down to the state universities; however, I found no evidence of efforts to involve U of I AFSCME members in encouraging their state leadership to pursue DPBs in the statewide contract. Ultimately, the coalition building in this effort centered around work with the Campus Senates rather than the plethora of unions throughout the U of I System. 


\section{Structure in the Groups}

As mentioned earlier, when considering the differences among group members and the role of organizational structure (or lack of structure) in contributing to the ultimate results of the effort, it is important to recognize that the structures of the DPB advocacy groups varied a great deal. These structures varied depending on the campus and the phase of the effort. The UIC group came from an officially recognized Chancellor's committee, with a budget. Although one could argue that the Chicago group was more cautious and less creative because of this recognition, they did have the respect of administrators.

On the other hand, the UIUC group had less structure, but used more creative approaches and was not focused on behind-the-scenes lobbying of administrators. They advocated for a public campaign in which multiple tactics were used. However, activism at Urbana was more student-oriented, sporadic, and grassroots when compared to the other two campuses, which could have been the cause of the UIUC effort falling apart after board approval of DPBs. Regardless, the UIUC group was quite active during numerous crucial times in the initial DPB approval process and their public campaign was the way Trustee Ritter was introduced to the issue.

When considering my framework of LGBTQ employee groups, it is possible to see this effort as having arms that took queer/radical approaches, internally responsive informal approaches, and conventional approaches. The relative association between these three campus groups resulted in work that had a significant impact in Neely concluding that the time was right to move forward on the proposal. This research uniquely contributes to the literature by discussing the interplay between these different types of groups working at multiple sites within the same employing organization.

\section{Exercise of Power}

The issue of structure within the groups raises another question about the university's tolerance level for activism and the bureaucratic control of activist efforts. Additionally, the governmental impulse toward administrative control raises the issue of the inadequacy of DPBs and the need for governmental recognition of same-sex relationships.

Making demands and making requests. As mentioned earlier, change happens at this university based on lobbying, pressure, and activism. Interestingly, the administration and Board of Trustees at the U of I does not "like to respond to pressure," as indicated by former Chancellor Susan Rozen. A corporate LGBTQ activist said, "we don't make demands-we make requests" (Raeburn, 2004, p. 213). At the U of I, the DPB activism was a bit stronger than "making requests," given the freedom allowed in a university environment. Of course, discourse varied in this loosely organized movement, depending on who was involved. In contrast, corporate environments have less tolerance for desperate messages, with their tightly disciplined cultures (Raeburn, 2004). Raeburn provides the example of corporate groups avoiding union-like phrases such as "equal pay for equal work" and instead using discourse around "fairness" and "respect." After the U of I advocates became frustrated when the board postponed votes on DPBs, they did in fact organize a rally around the theme of "Equal Work, Equal Pay." In university environments, discussion of equality and rights is much more mainstream and carries more weight when compared to corporations (e.g., Raeburn, 2004). However, activists continuously 
balanced their desire to make demands with the reality that heated rhetoric might not work with this board, as evidenced by the fight over the UIUC mascot.

Self-surveillance and employer-imposed structure. The tone of a message can vary depending on the self-surveillance imposed by the system. It's important to consider that "outness" can result in a state of mind that creates a self-surveillance due to the desire to be perceived as normal (Capper, 1999). This idea could explain some of hesitation and reluctance to "make waves" on the part of the activists. This was seen through claims that everyone should have been happy that President Neely was advocating for the benefits, even though he was advocating a substandard reimbursement scheme and was excluding opposite-sex couples.

\section{Implications for Research}

A major contribution of the study is in helping us to understand how disparate LGBTQ employee groups work together in seeking change within a large institution. Specifically, these groups worked toward the same goals while advocating different means for attaining those goals. In the end, the synergy created from these groups resulted in a movement that succeeded in many of its goals. In adding to existing research, the study helped to expand on theories of organizational development and change by illustrating the intersection of employee-initiated change efforts, LGBT identity-oriented approaches to organizing, and queer approaches to organizing. Future theoretical work can consider how this research influences models of organization development and change, especially given its location from within a universitybased employee-initiated effort.

In considering the interplay between identity-oriented approaches and queer approaches, I found that queer coalition-building approaches helped to advance the issue and gave it significance among the faculty. However, those queer coalitional ideas were seemingly abandoned in the latter stages due to a lack of administrator support and lack of coalitional labor. Additionally, some activists made significant moves to integrate unions and economic issues into the DPB effort; however, those efforts were isolated and not widespread. Future research could examine cases where coalitions sustained and where DPB efforts were more integrated with labor unions. Unfortunately, work for DPBs between labor unions and non-union groups is rare (Holcomb, 1999; Raeburn, 2004). Other research could consider coalitional ideas such as "convergence activism" in which flexible cells of "leaderless" groups protest and work toward change while maintaining individual group identities (Hill, 2004; Klein, 2000).

I concluded that HR within this university took a largely reactive stance. Further research could tease out the tensions between HR and activists. Utilizing concepts from critical HRD (e.g., Bierema, 2010; Bierema \& D'Abundo, 2003; Fenwick, 2004), research could explore how HR practitioners can better encourage and support such efforts. In this case study, HR remained largely reactive for almost 20 years. By exploring employee relations and retention issues, research could examine why employees continue to remain employed in seemingly unsupportive organizations. Research could explore whether LGBTQ employees are more tolerant of inequity in state institutions because of their democratic nature and the perceived potential for brining policy changes. Approached another way, research might consider the parallels between citizens bringing public policy changes and employees bringing policy changes in a state university. However, in light of the privatization of public universities, parallels between the state and state universities might not remain intact. 


\section{Implications for Practice}

This study calls into question how LGBTQ activists can maintain a commitment to broadly inclusive queer ideals when non-LGBTQ people stop working on an effort. Activists should consider how to better integrate queer concerns so that these efforts can be sustained over the long term. In this study, the queer goal of integrating opposite-sex and same-sex benefits was dropped with relatively little struggle after the DPB activists realized the President's opposition to fully inclusive DPBs. LGBTQ activists can consider how best to maintain a full commitment to that goal. I conclude that this commitment would have been sustained had the group made more efforts to work with the many unions in the university system, beyond the AAP.

Most importantly, this study presents workplace activists and other organizational development and change practitioners with an account of HRD occurring through an employeeinitiated effort. HRD practitioners in other types of organizations can learn from both the strengths and weaknesses of the university change process. On the positive side, the tolerant atmosphere allows many employees to feel comfortable challenging their employer in a more assertive manner than what we see in other sectors (Raeburn, 2004). This latitude allows for exploration of new ideas and approaches. On the negative side, the culture of bureaucratic cautiousness seems to take precedence over employee relations issues. This culture results in disgruntled employees and wasted energy on the part of activists and administrators. One could question whether the efforts to refine DPBs were the best use of people's time, especially when considering how easily the issues could have been resolved with top administrator support or board approval. When considering HR's lack of responsiveness, the study helps activists reconsider the extent to which HR should be relied upon to make these changes.

\section{References}

Alexander, J. (1999). Beyond identity: Queer values and community. International Journal of Sexuality and Gender Studies, 4(4), 293-314.

Anderson, G. L., Herr, K., \& Nihlen, A. S. (1994). Studying your own school: An educator's guide to qualitative practitioner research. Thousand Oaks, CA: Corwin Press.

Bierema, L. L. (2005). Women's networks: A career development intervention or impediment? Human Resource Development International, 8(2), 207-224.

Bierema, L. L. (2010). Critical organization development for human resource development and adult education. Malabar, FL: Krieger.

Bierema, L. L., \& Cseh, M. (2003). Evaluating AHRD research using a feminist research framework. Human Resource Development Quarterly, 14(1), 5-26.

Bierema, L. L., \& D'Abundo, M. (2003). Socially conscious HRD. In A. M. Gilley, J. L. Callahan \& L. L. Bierema (Eds.), Critical issues in HRD: A new agenda for the twentyfirst century (pp. 215-234). Reading, MA: Perseus.

Brennan, M., \& Noffke, S. E. (1997). Uses of data in action research. In T. R. Carson \& D. J. Sumara (Eds.), Action research as a living practice (pp. 23-43). New York: Peter Lang.

Burrell, G., \& Morgan, G. (1979). Sociological paradigms and organisational analysis: Elements of the sociology of corporate life. London: Heinemann.

Capper, C. A. (1999). (Homo)sexualities, organizations, and administration: Possibilities for in(queer)y. Educational Researcher, 28(5), 4-11. 
Colgan, F., Creegan, C., McKearney, A., \& Wright, T. (2006). Lesbian, gay and bisexual workers, equality, diversity and inclusion in the workplace. London: Comparative Organisation and Equality Research Centre, London Metropolitan University.

Colgan, F., \& Ledwith, S. (2000). Diversity, identities and strategies of women trade union activists. Gender, Work and Organization, 7(4), 242-257.

Creed, W. E. D., \& Scully, M. A. (2000). Songs of ourselves: Employees' deployment of social identity in workplace encounters. Journal of Management Inquiry, 9(4), 391-412.

Cummings, T. G., \& Worley, C. G. (2005). Organization development and change (8th ed.). Mason, $\mathrm{OH}$ : Thomson/South-Western.

D'Emilio, J., \& Freedman, E. B. (1997). Intimate matters: A history of sexuality in America (2nd ed.). Chicago: University of Chicago Press.

Davidson, J. W., \& Lytle, M. H. (1992). After the fact: The art of historical detection (3rd ed.). New York: McGraw-Hill.

Duggan, L. (2003). The twilight of equality? Neoliberalism, cultural politics, and the attack on democracy. Boston: Beacon Press.

Fenwick, T. J. (2004). Toward a critical HRD in theory and practice. Adult Education Quarterly, 54(3), 193-209.

Fisher, C. (2005). HRD attitudes: Or the roles and ethical stances of human resource developers. Human Resource Development International, 8(2), 239-255.

Gamson, J. (1995). Must identity movements self-destruct? A queer dilemma. Social Problems, $42(3), 390-407$.

Githens, R. P. (2009). Capitalism, identity politics, and queerness converge: LGBT employee resource groups. New Horizons in Adult Education and Human Resource Development, 23(3), 18-31.

Githens, R. P., \& Aragon, S. R. (2009). LGBT employee groups: Goals and organizational structures. Advances in Developing Human Resources, 11(1), 121-135.

Heyes, C. (2002). Identity politics. In E. N. Zalta (Ed.), The Stanford Encyclopedia of Philosophy (Fall 2002 ed.).

Hill, R. (2004). Activism as practice: Some queer considerations. New Directions for Adult and Continuing Education, 102, 85-94.

Hobson, D. (2001). Action and reflection: Narrative and journaling in teacher research. In G. E. Burnaford, J. Fischer \& D. Hobson (Eds.), Teachers doing research: The power of action through inquiry (2nd ed., pp. 7-27). Mahwah, N.J.: Erlbaum.

Holcomb, D. (1999). Domestic partner health benefits: The corporate model vs. the union model. In G. Hunt (Ed.), Laboring for rights: Unions and sexual diversity across nations (pp. 103-120). Philadelphia: Temple University Press.

Human Rights Campaign Foundation (2012). Workplace database Retrieved March 16, 2012, from http://www.hrc.org/employersearch/

Klein, N. (2000). The vision thing. The Nation Retrieved April 21, 2008, from $\mathrm{http} / / / \mathrm{www} \cdot$ thenation.com/doc/20000710/klein

Meyerson, D. E., \& Scully, M. A. (1995). Tempered radicalism and politics of ambivalence and change. Organization Science, 6(5), 585-600.

Patton, M. Q. (2002). Qualitative research and evaluation methods (3rd ed.). Thousand Oaks, CA: Sage.

Raeburn, N. C. (2004). Changing corporate America from inside out: Lesbian and gay workplace rights. Minneapolis: University of Minnesota Press. 
Risdon, C., Cook, D., \& Willms, D. (2000). Gay and lesbian physicians in training: A qualitative study. Canadian Medical Association Journal, 162(3), 331-334.

Schön, D. A. (1987). Educating the reflective practitioner: Toward a new design for teaching and learning in the professions (1st ed.). San Francisco: Jossey-Bass.

Scully, M., \& Segal, A. (2002). Passion with an umbrella: Grassroots activists in the workplace. In M. Lounsbury \& M. J. Ventresca (Eds.), Social structure and organizations revisited (Vol. 19, pp. 125-168). San Diego, CA: Elsevier Science.

Sedgwick, E. K. (1990). Epistemology of the closet. Berkeley: University of California Press.

Stake, R. E. (1995). The art of case study research. Thousand Oaks, CA: Sage.

Taylor, V., \& Raeburn, N. C. (1995). Identity politics as high-risk activism: Career consequences for lesbian, gay, and bisexual sociologists. Social Problems, 42(2), 252-273.

Torraco, R. J. (2005). Organization development and change in universities (whole issue). Advances in Developing Human Resources, 7(3).

Torraco, R. J., \& Hoover, R. E. (2005). Organization development and change in universities: Implications for research and practice. Advances in Developing Human Resources, 7(3), 422-437.

Whittington, R. (2001). What is strategy - and does it matter? (2nd ed.). London: International Thomson. 